\title{
Review on Opportunities and Constraints of Fishery in Ethiopia
}

\author{
Tola Meko, Abriham Kebede* Abdela Hussein and Yobsan Tamiru
}

School of Veterinary Medicine, College of Medical and Health Science, Wollega University, Nekemte, Ethiopia

Received: November 13, 2017; Accepted: December 4, 2017; Published: December 21, 2017

*Corresponding author: Abriham Kebede, School of Veterinary Medicine, College of Medical and Health Science, Wollega University, P.O.Box, 395, Nekemte, Ethiopia, Tel: +251-917-095-077; E-mail: abrahamkebede2016@gmail.com

\section{Summary}

Fish has historically played an important role in food security in many countries and contributes to do so in globally, providing $15-20$ percent of animal protein intake. Fishery has been practiced in different parts of the world. At present, the country Ethiopia has an estimated annual total exploitable fish potential of 51,481 tons, which can meet only 79 percent of the current actual demand, 55 percent of the projected demand in 2010 and 44 percent of the projected demand in 2015, based solely on population size. Ethiopia contains many lakes and rivers for fish production and also different species of fishes exist in these lakes and rivers. In addition to this there is good environmental condition for fishery and there is huge agricultural and Industrial by Product or residue due to the country mostly based on agriculture and also few industry to sustain the life of the people. Using of these opportunities fishery is an alternative means achieving food security and poverty reduction in Ethiopia. In spite of these opportunities, fishery sector of the economy has various problems, among others climate change, mismanagement of the resource, inappropriate policies and institution, inadequate technical and material backup to the sector and market are the major ones. The objective of this paper is to review the opportunities and challenges of fisheries in Ethiopia. Due to these challenges fishery is still an infant which means cannot fill the need of the demand. Therefore, the government and private should take consideration for fishery sub sector to increase productivity and gross domestic product of the country by alleviating these challenges.

Key words: Constraint; Ethiopia; Fish; Fishery; Opportunity;

\section{Introduction}

Fish farming has been practiced in different parts of the world like Europe, Canada, East Asia, China, Africa and developing countries like Nigeria [1]. It has been in practice since the ancient civilization of Egypt and China. More than 120 million people throughout the world are estimated to depend on fish for all or part of their income. Conservation of communities implies knowledge of the number and distribution of species of any particular area. As habitat degradation continues on a global scale, maintenance of species richness has become a central issue of conservation biology [2].

It is estimated that the inland fisheries of Africa produce 2.1 million tons of fish, which represents $24 \%$ of the total global production from inland waters [3]. According to Food and agricultural organization (1) in developing countries accounted for 49 percent of world exports. With growing trade in fish products, there is growing concern about the possible effects on developing country consumption and nutrition [4]. Ethiopia is the largest livestock populations in the Africa. The livestock sector accounts for over 26 percent of agricultural GDP (2009/10) and 8 percent of export earnings (2010) and can produce over 51,500 tons of fish per annum. However, their exploitation and consequently their contributions to food security and growth in the country are minimal despite the technologies capable of resolving the problems of livestock and fisheries production [5].

At present, the country Ethiopia has an estimated annual total exploitable fish potential of 51,481 tons, which can meet only 79 percent of the current actual demand, 55 percent of the projected demand in 2010 and44 percent of the projected demand in 2015, based solely on population size [6]. Fish is highly nutritious, so even small quantities can improve people's diets. Fish provides about 20 percent of animal protein intake in developing countries and this can reach 90 percent in Small Island Developing States or coastal areas Fisheries can also contribute indirectly to food security by providing revenue for food- deficient countries to purchase food Fish exports from low-income, food-deficient countries are equivalent to 50 percent of the cost of their food imports [7].

The inland water body of Ethiopia is estimated to encompass about 7,400 km 2 of lake area and a total river length of about 7,000 $\mathrm{km}$. As many other countries challenged in the world, population rise urbanization, agricultural development, industrialization and other water resource development activities have resulted in a decrease in the species diversity of freshwater fish species. Fisheries production is also under-exploited while current demand exceeds supply by about four-fold. One of the big and immediate challenges of our country is addressing the problems of food security and poverty [8].

Currently, about $45 \%$ of the total population is living under poverty and the level of impoverishment is worse in rural areas, where $85 \%$ of the total inhabitants' dwell [9]. Artisanal freshwater fishery is one of the most important economic activities in Ethiopia, [10]. Improvements in fishery sector would contribute 
to poverty alleviation and environmental sustainability in Ethiopia [11]. The benefits gained from the development of fisheries are significant. From local to global levels, fisheries and aquaculture play important roles in food supply, income generation and nutrition [12].

It is apparent that aquaculture in Ethiopia remains more potential than actual practice or is non-existent; despite the fact that the country's physical and socio-economic conditions support its development [6]. There are many rivers and lake available in Ethiopia which used for a fish production, but there is still a problem regarding fish production and productivity to increase the profit of private and GDP of the country.

Therefore, the objectives of this seminar are:

1. To review the Opportunity and challenges of Fishery in Ethiopia and the status of the Fish Production and Management in Ethiopia

2. To provide recommendation for future development of fishery in the country

\section{Fishery in Ethiopia}

Ethiopia has a rich diversity of Ichthyo-fauna in its lakes, rivers and reservoirs, although they are poorly known [13]. The highest fish species two diversity in Ethiopia has been recorded from Baro basin, followed by Abay, Wabishebele and Omo-Gibe basins. However, endemicity seems to be highest in Abay and A washbasins. This is attributed, in the former case, to the endemic species flock of Labeo barbus in Lake Tana [14].

Fish today provides the main source of animal protein for 20 percent of the world's population. At the same time, some 40 percent of the global fish production is traded internationally. During the period 1982-2002, the net exports of fishery commodities by developing countries (i.e. deducting their imports from the total value of their exports) increased from US\$ 4.0 billion to $\$ 17.4$ billion. This was greater than the net exports of other agricultural commodities, such as rice, cocoa, tobacco, and tea. Fish is indeed a global good, caught all around the world and exported for trade almost everywhere. The global seafood market offers a lot of opportunities, but also raises challenges in terms of how such aquatic resources are managed [15].

\section{Opportunities of Fisher in Ethiopia}

Ethiopian aquaculture is recognized as an alternative means of achieving food security in particular and poverty reduction in general, and is now considered as an integral part of rural and agricultural development strategies. Ethiopia has an estimated live water body of 7,334 $\mathrm{km} 2$ of major lakes and reservoirs, and $275 \mathrm{~km} 2$ of small water bodies, with 7,185 km of rivers within the country. The country has only inland freshwater fisheries. The inland fishery comprises Rift Valley lakes (such as lakes Chamo, Abaya and Ziway), Lake Tana, Lake Hashenge, Baro and Tekeze Rivers. There is fishing in all these water bodies, but commercializing it is mainly concentrated around lakes such as Chamo, Ziway (Southern Ethiopia) and Tana (North-Western Ethiopia). Hence, the existing role of fishery is insignificant in the country's overall economy because the fishery sector in the country is far below its potential [16]. Approximately 15,000 fishermen are currently employed in this sector signifying that fishing practice in the country is still in its infancy stage with an average production of about 12,300 tons in 2002 [17].

\section{Environmental Condition}

Ethiopia has diverse wetlands of various origins that distributed in many parts of the country. A large number of Ethiopians depend on wetland resources for their survival [18]. With the exception of coastal and marine related wetlands and extensive swamp forest complexes, all forms of wetlands are present in Ethiopia. Major rivers and lake systems, together with their associated wetlands, are fundamental parts of life interwoven into the structure and welfare of societies and natural ecosystems [19].

In Ethiopia, wetlands are distributed across different ecological ranges. The Rift valley ecosystem is one of these ecological systems and provide ecological functions which maintain and protect nature and human systems through services such as the maintenance of water quality, flow and storage, flood control, sand storm protection, nutrient retention and micro climatic stabilization, along with the production and consumption activities that they support. The whole Rift valley ecosystem, including its wetland drainage system and up lands, is regarded as a rich strategic site for a wide variety of resident and migratory avifauna population [20].

\section{Ichthyologic Fauna}

There are seasonal variations in the availability of different types of fish, but as there are some differences between the lakes, traders can smooth out supply to some extent. There are 180 different species of fish in Ethiopia and 30 of those are native to the country. For the sake of convenience, the country's water bodies are classified into four systems: lakes, reservoirs, rivers and small water bodies [21]. The lakes and rivers support highly diverse aquatic life, ranging from giant mammals like the African Hippopotamus, to microscopic fauna and flora. The importance of fish products in many coastal, lake and floodplain areas is very much greater than this global average [22].

The main commercial species contributing to the total landing are Oreochromis niloticus, Labeo hori, Clarias gariepinus, Barbus species and Lates niloticus [23]. The main species are Nile tilapia, representing $60 \%$ of the catch, [24]. Nile perch (favored but increasingly), barbus (two species) and catfish are scarce. Besides, to its captured fisheries importance, Tilapia is one of the most important species for 21 century aquaculture stand is produced in more than 100 countries [25].

Tilapia is the leading species caught and consumed in Ethiopia, although this does not seize for all groups and for all areas. This is reported by different researchers, Nile Tilapia (Oreochromis niloticus) is the dominant fish species of the landings [26]. The first information about an Ethiopian fish probably appeared in the narrative of the Portuguese 
Embassy sent to Ethiopia in 1520 [27]. In the sixties, seventies and early eighties, there was little progress in discovering new fishes in the Ethiopian inland water [28].

Over 35 fish species have been described from the Rift Valley Lakes and the Lower Omo River Basin. The fish fauna is more diverse in the Southern Rift valley lakes of Abaya and Chamo and in the Lower Omo River basin. The waters of Lake Turkana, which span the Ethiopian - Kenyan border, have high fish species diversity. Many of these migrate up the Omo River to spawn. Few studies have been carried out on the diversity level and the ecological status of this trans-boundary aquatic resource [29].

\section{Water Bodies}

Ethiopia is endowed with several water bodies that contain a high diversity of aquatic fauna. The inland water body of Ethiopia is estimated to be 7,400 km of lake area and about 7,000 km total length of rivers [30]. The main drainage basins of Ethiopia are flowing away from the rift system either towards the Nile system in the west or to the Indian Ocean in the Southeast. The Ethiopian fresh water systems can be classified into seven drainage basins. These are the Abay, Awash, Baro Akobo, Omo-Gibe, Rift Lakes, Tekeze and Wabishebele-Genale basins [31].

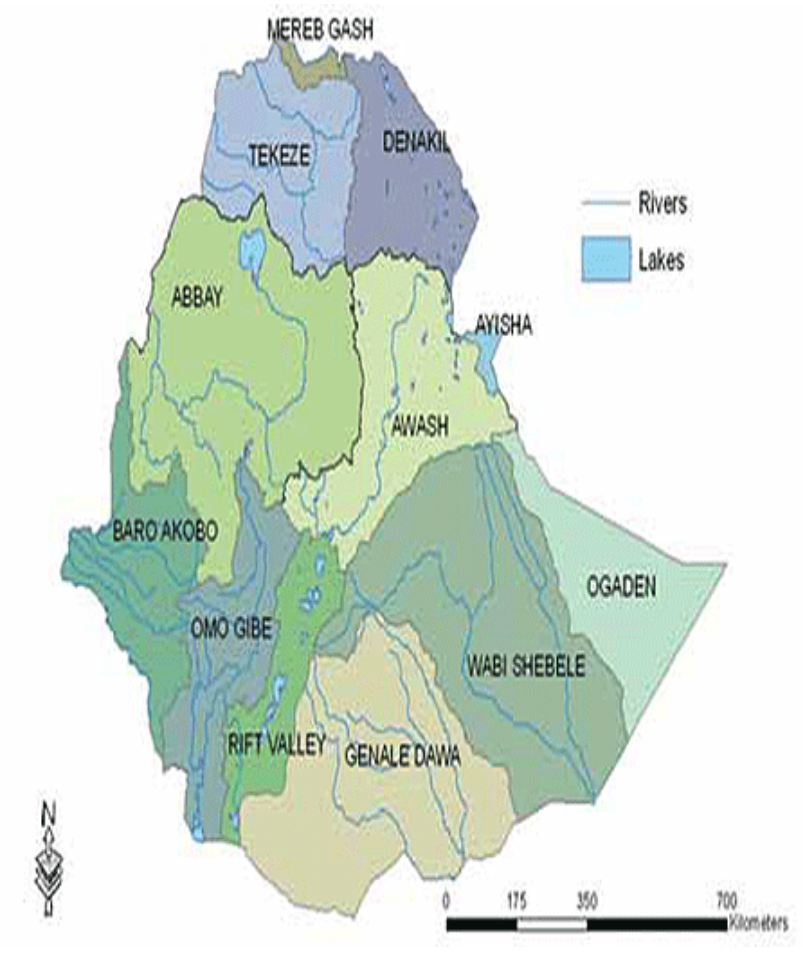

Figure 1: A map showing the main river basins of Ethiopia Source: (Molle, 2006).

Blue Nile (Abay) Basin: The Nile River is the longest in Africa and the second longest in the world. It flows $6,700 \mathrm{~km}$ from its source in the equatorial lake basin to the Mediterranean Sea north of Cairo, Egypt. In between, it receives flows from a major tributary, the Blue Nile from the Ethiopian highland plateau, which contributes significantly to the Nile River's total annual flow of
Table 1: Number of fish species and endemic species in Ethiopian drainage

\begin{tabular}{|c|c|c|}
\hline Drainage basin & No. of species & $\begin{array}{c}\text { No. of endemic } \\
\text { species }\end{array}$ \\
\hline Blue Nile & 36 & 23 \\
\hline Awash & 15 & 6 \\
\hline Baro & 87 & 1 \\
\hline Omo & 26 & 2 \\
\hline Riftvally Lakes & 32 & 7 \\
\hline Wabishebele & 26 & 4 \\
\hline Tekeze & 10 & - \\
\hline Source: Getahun, 2007 & & \\
\hline
\end{tabular}

almost 84 billion m per year at Aswan, Egypt. Blue Nile (Abay) river basin has a catchment area of $198,890.7 \mathrm{~km}$, covering parts of Amhara and Oromia and Benishangul-Gumuz regional states of Ethiopia. The Abay Basin is one of the tributaries of White Nile and consists of 36 species of fish which 23 are endemic. Most of the endemic species occur exclusively in Lake Tana. Some of the families of fishes identified with in the Abay and tributary rivers are Mormyridae, Characidae, Cyprinidae, Bagridae, Scheilbeidae, Mockokidae and Cichlidae [33].

Endemicity seems to be highest in Abay (Blue Nile) basin. This is attributed, in the former case, to the endemic species flock of Labeo barbus in Lake Tana [14]. Lake Tana is a lake in the northern highlands of Ethiopia and is the source of the Blue Nile. The Blue Nile descends from Lake Tana to Tisisat Falls (ca. $40 \mathrm{~m}$ high), effectively isolating the lake's freshwater fauna from the rest of the Nile [34]. Lake Tana from Abay drainage basin exclusively has larger number of endemic species (Eighteen species) in the country [35]. A total seventeen fish species were recorded in upper head of Blue Nile River [36].

Awash River Basin: The Awash River rises on the high plateau of Showa and flows northwards following the Great Rift Valley where it disappears in the desert near the Djibouti border. This river basin is the most agriculturally important river basin in Ethiopia and covers a total land important river basin in Ethiopia and covers a total land area of $110,000 \mathrm{~km}$ and serves as home to 10.5 million inhabitants. Awash River basin has a catchment area of 110,439.3 km. It covers parts of the Amhara, Oromia, and Afar, 2 Somali, Dire Dawa and Addis Ababa states of the country. Therefore, Awash River and its tributaries drain the central highlands, the eastern and north-eastern lowlands. A total of 10 species of fish were described from Awash River and its tributaries [37].

Tekeze Basin: The Tekeze River basin is located in the northwest of Ethiopia, between $11^{\circ} 40^{\prime}$ and $15^{\circ} 12^{\prime}$ north and longitude of $36^{\circ} 30^{\prime}$ and $39^{\circ} 50^{\prime}$ east. The area of the basin is about $84,000 \mathrm{~km}$. The elevation ranges from 537 to 4,517 meters above sea level. About $70 \%$ of the basin falls in the highlands at altitude of above 1,500m.a.s.l. The upper part of the basin is dominated by rugged mountains while the western part of the basin is almost flat or slightly undulating [38]. 
The Tekeze Basin includes the Tekeze, Angereb and Guang sub-basins. The three rivers form together the Atbara River (In Sudan), which is a tributary of White Nile system entering the Nile downstream from Khartoum. The annual rainfall of the basin shows high variation. It ranges from $5,000 \mathrm{~mm}$ in the western part to $1,300 \mathrm{~mm}$ in the highlands of the basin. The Tekeze Basin is the least diverse in fish species compared to the other part of the Nile basin within the limits of Ethiopia. This could be because of the tremendous seasonal variation of water discharge in the system [27]. Some interesting Nilo-Sudanic and east African genera from the Rivers of Shinfa and Ghendwuha which are found in Metema District, North Gondar [39].

Rift valley Basins: The Ethiopian Rift Valley, being the northern part of the East African Rift system, can be divided into three main zones differing in their geological structure. The Afar Rift Systems the main Ethiopian Rift of central Ethiopia and the broadly rifted zone of south western Ethiopia. The Rift Valley is South of Addis Ababa contains a system of small to medium-sized lakes, some of which are saline [30].

The most fished lakes are Ziway, Langano, Awassa, Chamo and Abaya. Also exploited for fishing are the two largest reservoirs, Fincha and Koka. The Ethiopian Rift Valley encompasses several isolated major basins, as well as a number of smaller isolated basins, mostly the crater lakes. The major basins are as follows: the Awash River drainage in the north; two systems of linked lakes (Zwai-Langano-Abijata-Shalla and Awasa-Shallo) and connected lotic waters in the central part; lakes Abaya, Chamo and Chew Bahir and in the south. Lake Turkana and the lower reaches of the Omo River occur in the northern their tributaries Kenya Rift, which is connected with the Main Ethiopian Rift of central Ethiopia by a 300-km-wide zone of overlap [40].

The Abaya and Chamo basins occupy the southern part of the Main Ethiopian Rift of central Ethiopia, whereas the Chew Bahir basin occurs in the zone of overlap of the main Ethiopian and northern Kenya Rift systems. The Rift valley is the region with highest number of introduced fish species. The fish fauna of the Ethiopian Rift Valley is characterized by a reduced number of species compared to the neighboring regions belonging to catchment areas of the Atlantic and Indian Oceans [27].

Omo- Gibe Basin: The Omo-Gibe River basin is known to contain high diversity of fish species with over 70 species listed. The fishery in the Omo basin includes: the riverine fishery along the main stream Omo River, flood plain fishery (Dipa Haik) and the lacustrine fishery at Lake Turkana (Bubua and Toltal) reported a total of 12 species were recorded in the Omo-Gibe basin Baro-Akobo Basin) [13]. However, more than 90 fish species were recorded by [41]. More recently, indicated that there are 113 fish species were recorded included in to 60 genera and 26 families. The diversity of fish fauna Baro drainage basins contains a mixture of Nilo-sudanic (Bagrus, Citharinus, Hydrocynus, Micralestus, Labeo, Mormyrus, Pollymirus and Polypterus), East African (Barbus, Clarias, Oreochromis and Sarothrodon) and endemic (Garra) forms [42].
Wabishebele Basin: The Wabi-Shebelle is the major river of the central Somali region. Rising between the Arsi and Bale Mountains, it flows in a southeasterly direction to Somalia. Wabi Shebelle, with a catchment area of 205,407 km, winds a length of $1340 \mathrm{~km}$ inside Ethiopia and a further $660 \mathrm{~km}$ in Somalia. The Wabi Gestro, the Ghenale River and the Dawa Parma River drain the southwestern escarpment of the eastern Ethiopian highlands. These rivers unite and become the Juba River, which eventually drains into the Indian Ocean. These Juba tributaries arise just east of Abaya and Chamo Lakes, but are separated from the lake drainages by a high mountainous divide Midway between the lower courses of the Wabi Shebelle and the Juba there is a lowlying limestone plateau with extensive underground waterways radiating out from it [43].

Agriculture in Ethiopia is the foundation of the country's economy, accounting for half of gross domestic product, $83.9 \%$ of exports, and $80 \%$ of total employment. Ethiopia's agriculture is plagued by periodic drought, soil degradation caused by overgrazing, deforestation, high levels of taxation and poor infrastructure (making it difficult and expensive to get goods to market). Yet agriculture is the country's most promising resource. A potential exists for self-sufficiency in grains and for export development in livestock, grains, vegetables, and fruits. As many as 4.6 million people need food assistance annually [44].

Numerous ways of crop by-product utilization exist amongst smallholder farmers (Preston, 1995). These may have a strong cultural and economic basis and may vary from society to society depending on the type of residue available [45]. In many developing countries, the feeding regimes aim to use crop residues and agro-industrial by-products as the principal component of the diet as these are the locally available and relatively cheap resources [46]. Reported that, crop residues provide 40 to $50 \%$ of the animal feed requirements in Ethiopia.

\section{Constraints of Fishery in Ethiopia}

\section{Environmental Degradation}

Due to increases in subsistence agricultural growth, deforestation, municipal and industrial effluents and human encroachment on the shoreline has given rise to historically unprecedented nutrient loadings into the lake [47]. Degradation and depletion has the most immediate impact on rural poverty, food insecurity, malnutrition and under-nutrition are closely linked to the degradation of environment, as poverty depletes natural resource, which in turn aggravates the suffering of the rural poor. When people's survival is at stake they are forced to farm marginal lands, to reduce fallow periods, to cut vital forests in their search for arable land or fuel, to overstock fragile rangelands and to over Fish Rivers, lakes and coastal waters [48].

Nevertheless, the fishing sector of the economy has various problems, among others, mismanagement of the resource, inappropriate policies and institution, inadequate technical and material backup to the sector and market are the major ones. Moreover, the Ethiopian lakes, on which the inland fishing is mainly practiced, are threatened by catchment's deforestation, 
shore damage, water pollution, siltation and eutrophication and over fishing [49].

\section{Low Institutional Capacity}

The constraints and vulnerability of fisheries communities are mainly due to resource depletion increasing competition on open access resources, inequitable use of resources, natural disasters like storms and over-reliance on one type of asset and lack of options. Moreover, lack of government support, remote locations and poor services, low literacy and innumeracy and weak organization capacity are other factors that expose fishing communities to poverty. The number of fishermen and fishing gears increased the fishery resource has become so scarce and the common pool fishery resource which is the source of livelihood to the fishing communities become at risk [22].

The fish stocks decline and the demand for fish and seafood increases, illegal fishing and the trade of illegal fish is becoming an increasingly reactive option for some operators. At the same time governments around the world are working together to tighten the controls on fishing vessels, fishing activities, the transport of fish and the trade of fish in an effort to stop illegal fishing and to be manage their fishery and production problems [50].

\section{Limited Infrastructure Facilities and Equipment}

Road transport is the dominant transport system in Ethiopia, connecting urban-rural areas, and the country to regional ports. In the early 1990s, classified road network in Ethiopia was limited to about $23,000 \mathrm{~km}$, of which about $75 \%$ was rated as in poor condition. The Government has set out a Road Sector Development Program, with the aim of speeding up the improvement and expansion of the road network. The first three phases of the Road sector development program has seen significant improvements in the restoration and expansion of Ethiopia's road network [51].

As a result of the Road Sector Development Program investment, the total road network in Ethiopia has increased on average by about $4.2 \%$ each year. By June 2010 , the total classified road network had increased to $48,793 \mathrm{~km}$ (excluding community roads). This is an increase of some $22,243 \mathrm{~km}$ since the launch of the program in June 1997, giving a road density of $44.4 \mathrm{~km}$ per $1000 \mathrm{~km} 2$ and $0.58 \mathrm{~km}$ per 1000 population. By the end of Growth and Transformation Plan period, the road network is expected to reach $136,004 \mathrm{~km}$, increasing the proportion of road in acceptable condition to $86.7 \%$ in $2014 / 15$ [52].

\section{Climate Change}

Relevant current and future global climatic changes include an increase in mean air temperature, shifting precipitation patterns and an increase in extreme weather events. The impacts of climate change and variability on inland fisheries and aquaculture production will be different [53]. Production of fish in Sub- Saharan Africa is important not only for domestic food security, but also to community livelihoods and national economies. Climate change also poses threats to marine and freshwater species and habitats (World fish council [54].

Changes in global and regional climate will interact with many other factors which govern the distribution and ecology of the resources and influence the capacity and performance of the marine fisheries sector to meet future consumption rates Unlike most terrestrial animals, aquatic animal species are poikilothermic (cold-blooded) and changes in habitat temperatures will more rapidly and significantly influence metabolism, growth, reproduction and distribution, with stronger impact on fishing and aquaculture distribution and productivity. The interconnectedness of aquatic systems allows fish species to migrate with shifts in ecosystems conditions (55).

\section{The Growing Pollution of Aquatic Ecosystem}

In Ethiopia, there is now an urgent need for the development of effective EIA. As casual observation suggests and studies confirm the environment is not featured highly on the development agenda; the major preoccupation in project evaluation has been with short term technical feasibility and economic benefits. Many development practices have not anticipated, eliminated or mitigated potential environmental problems early in the planning process. This has resulted in a seriously degraded natural environment. For instance, according to a survey of 118 industrial establishments in Addis Ababa, waste containing hazardous pollutants has been discharged into all-purpose streams, water bodies and the air [56].

A survey conducted by the Environmental Protection Authority (EPA) also revealed that most factories located in Addis Ababa do not have any way of treating waste. Evident environmental illnesses in urban centers, especially in Addis Ababa, are the manifestations of the growing challenges [57]. Another study conducted by the EPA revealed that privatelyowned Ethiopian Coffee and Tea Development and Marketing PLC established the Gemadro Coffee Plantation Project without going through any EIA process, even using land that was not allocated to it [58].

\section{Lack of Tradition and Low Purchasing Power of Most the community}

The current annual per capita fish production is less than 240 g. Despite this, based on only a single factor - population for the year 2008 annual demand for the fish in the country was estimated at 65344 tons. Future demand at the present population growth rate will reach 83483 tons in the year 2015 . This is the minimum demand, since factors other than population are not considered. These positive factors, which trigger demand, include the relatively current low fish product price compared to the increasing prices of its substitutes: a rise in real income of the society; the growth and expansion of towns, and improvement and expansion in fish distribution or supply networks and improvement in fish product. At present, the country's estimated annual total exploitable, if fully exploited, can meet only $55 \%$ of the projected demand in 2010 and $44 \%$ of the projected demand in 2015, based solely on population size [17].

\section{Management of the Fishery}

The major cause appears to be the destructive fishing in the river mouths while the fish are in route to their spawning grounds 
upstream [59]. For the interests of the majority of the fishermen in lake Ziway, the management of fisheries is preferably to rely on closed seasons, closed fishing areas, restriction on number of fishers, catch quotas, mesh size restriction, restriction on beach seines and banning beach seines [60].

It has also been recognized that the efficiency and implement ability of the management measures are often highly dependent on the support gained from the interested parties' [61]. Reported integrate upstream forest and wet land protection and rehabilitation activities in to the conservation, development and management of water resources and protection of the interface between water bodies and land such as lake shores, river banks and wet land [62].

\section{Fish Diseases}

One of the problems of the fishery sector in the wild population are parasites and disease conditions of fish parasitic diseases reduce fish production by affecting the normal physiology of fish and if left uncontrolled, it can result in mass mortalities or in some cases, can be served as a source of infection for human and other vertebrates that consumed fish [63].

In both natural environments and in culture, disease has a serious impact on fish. Disease is universally recognized as one of the most serious threats to the commercial success of aquaculture [64]. Parasitic, bacterial, protozoan and viral diseases of fish are among those diseases which has great economic and public health importance particularly in the tropics [41]. In many cases, they have proved to be a serious problem causing economic losses in the fishing industry and in aquaculture. In fish farming they may lead to epidemics and mortalities, and as the culture of fish becomes more intensive and widely spread, fish parasites infection will be more liable to become more serious economic and health issues [65].

\section{Conclusion and Recommendations}

From local to global levels, fisheries play important roles in food supply, income generation and nutrition. Ethiopia contains many lakes and rivers for fish production and also different species of fishes exist in these lakes and rivers. In addition to this there is good environmental condition that can be conducive for fishery and there is huge agricultural and Industrial by Product/residue due to the country mostly based on agriculture and also few industry to sustain the life of the people. Using of these opportunities fishery is an alternative means achieving food security in particular and poverty reduction in general in Ethiopia. The fishing sector of the economy has various problems, among others climate change, mismanagement of the resource, inappropriate policies and institution, inadequate technical and material backup to the sector and market are the major ones. Even though, there are certain opportunities for fishery in the country, fish production is still an infant.

Based on the above conclusion the following recommendations are forwarded:

- Awareness creation on fish welfare and production through training, extension service should be encouraged by the concerned bodies.

- The government should take consideration about infrastructure activities of fish production.

-Giving Capacity building in various aspects of resource management

- Improve policies for enhancing private sector investments in fishery development.

- Further research should be conducted to explore abundance of fish species and fish diseases.

\section{Acknowledgement}

We were like to express our gratitude to Wollega University, College of Medical and health science, School of Veterinary Medicine and the Staff of School of Veterinary Medicine for inspiration and comprehensive moral support that enabled me succeed throughout my work.

\section{References}

1. Ameha, A, Assefa A. The fate of the barbs of Gumara River, Ethiopia. SINET Ethiopian Journal of Science. 2002;25(1):1-18.

2. Assefa, M.J. The contributions of fishery to food security and growth in the country. Research Journal of Agriculture and Environmental Management. 2014;3(9):460-466.

3. Ayalew W. Current status and future challenges of fisheries in Lake Tana. Proceeding of the National Consultation and Promotional Workshop on Lake Tana and its Environs:Conservation, Utilization, Development and Threats.2006;Pp:130-143.

4. Ayotunde E, OChang S, Okey, IB. Parasitological examination and food composition in the gut of Feral African carp, lebeo coubie in the Cross River, south Eastern, Nigeria. Afr J Biotechnol. 2007;Pp: 625-630.

5. Berkes F, Mahon R, McConney, Richard P, Robert P. Managing Small- Scale Fisheries; Alternative Directions and Methods. Ottawa. International Development Research Centre. 2001.

6. Bizuwo A, Taddese G, Sonder K, Peden D, Jobre Y. Comparative assessment of forage and livestock density in Tekeze River Basin. Ethiopia. AGRIS. 2006;10:25-36.

7. Breuil C. Review of the Fisheries and Aquaculture Sector: Ethiopia. FAO Fisheries Circular. No. 890.1995;Pp: 29.

8. Cochrane K, De Young C, Soto D, Bahri T. Climate change implications for fisheries and aquaculture: overview of current scientific knowledge. FAO Fisheries and Aquaculture Technical Paper. No. 530. 2009.

9. Daw T, Neil Adger W, Brown K, Badjeck M.Climate change and capture fisheries. University of East Anglia. Norwich. World Fish Center. Penang.2008.

10.Dereje T. Spatial and temporal distributions and some biological aspects of commercially important fish species of Lake Tana, Ethiopia. J Coastal Life Med. 2014;2(8): 589-595.

11. Desta M. Industrial Waste Management System for Akaki River:A Study Report. Addis Ababa.1989.

12. Dixon AB. Indigenous Management of Wetlands: Experiences in Ethiopia. 2003;258 pp. 
13. Ebinger C, Yemane, D Harding, S Tesfaye, S Kelley, Rex D. Rift deflection, migration and propagation: linkage of the Ethiopian and eastern rifts, Africa. GSA Bulletin. 2000;112(2):163-176. DOI:10.1130/00167606(2000)112<163:RDMAPL $>2.0 . C 0 ; 2$

14. Environmental Protection Authority (EPA). Management plan for the conservation and sustainable utilization of Abaya and Chamo wetland. Addis Ababa, Ethiopia. 2005.

15. Federal Democratic Republic of Ethiopia (FDRE). Environmental Policy of Ethiopia. 1997

16. Felegeselam Y. Management of Lake Ziway fisheries in Ethiopia. Thesis of Master of Science in International Fisheries Management. Department of Economics, Norwegian College of Fishery Science, University of Tromsø. 2003.

17. Fitzsimmons K. Tilapia: the most important aquaculture species of the 21st century. Tilapia aquaculture in the 21st century. Proceedings from the Fifth International Symposium on Tilapia Aquaculture. 2004:3-8.

18. Food and agricultural development (FAD). Sustainable Fisheries Livelihoods Program: Study on the Impacts of Policies Institutions and Processes on Fisheries Livelihoods in Ghana. 2001.

19. Food and Agricultural Organization (FAO). Fishery Statistics. Food and Agriculture Organization of United Nations. Rome Italy. 2003;96(1): 251.

20. Food and Agricultural Organization (FAO). Code of conduct for responsible fisheries, Rome. 2003b.

21. Food and Agricultural Organization (FAO). Fishery country profile, Ethiopia. 2003.

22. Food and Agricultural Organization (FAO), (2004). The State of World Fisheries and Aquaculture Report.

23. James W Miller. Food and agricultural organization (FAO). Farm Pond for Water, Fish and Livelihood, FAO, Rome. 2009.

24. Food and Agricultural Organization (FAO). Climate Change, Inland Fishery and Aquaculture e in Africa: Back ground Information. Committee for in land Fisheries and Aquaculture of Africa. Sixteenth Session. Maputo. November. 2010.

25. Food and Agricultural Organization (FAO). Fishery and Aquaculture Country Profiles Ethiopia. Fisheries and Aquaculture Department. 2012.

26. Gebremariam Z, Dadebo E. Water resources and fisheries management in the Ethiopian Rift Valley lakes. SINET: Ethiop J Sci.1989;12(2): 95109.

27. Getahun A. The Nile Basin: Riverine Fish and Fisheries. Deptartment of Biology Addis Ababa University Ethiopia. 2002:19.

28. Getahun, A. An overview of the diversity and conservation status of the Ethiopian freshwater fish fauna.In proceeding of the Pan- African fish and fisheries society, Cotonou, Benin. 2005.

29. Getahun A. An overview of the diversity and conservation status of the Ethiopian fresh water fish fauna. J Afro-tropical Zoology special Issue. 2007:87-96.

30. Getahun A, Dejen E, Anteneh W. Ethiopian Nile Irrigation and Drainage Project. 2008

31. Global Fish Alliance, The importance of capture fisheries in food security in Ethiopia. Fact sheets on state of fisheries in African countries. 2010.
32. Golubstov A, Darkov A, Dgebuadze Y, Mina M. An artificial key to fish species of the Gambella region (The White Nile basin in the limits of Ethiopia). Joint Ethio- Russian Biological expedition. Addis Ababa, Ethiopia. 1995:84.

33. Golubtsov A, Darkov A. A review of fish diversity in the main drainage systems of Ethiopia2008:69-102.

34. Golubtsov A, Mina, M. Fish species diversity in the main drainage systems of Ethiopia;current state of knowledge and research perspectives. Ethiop J Natu Reso. 2003;5(2):281-318.

35. Gordon A, Finegold C, Charles C, Alan P. Fish Production, Consumption and Trade in Sub-Saharan Africa. 2013.

36. Joint Ethio-Russian Biological Expedition (JERBE). Fish diversity in the main drainage systems of Ethiopia. Addis Ababa, Ethiopia. Unpublished manuscript.2007

37. Keftasa D. Role of crop residues in Ethiopian highlands. In B. H. Dzowela (ed), African forage plant genetic resources, evaluation of forage germ plasm and extensive livestock production systems. Proceeding of the third 3rd Workshop held at the International Conference Center. Arusha, Tanzania. 27-30 April 1987. ILCA. Addis Ababa. Ethiopia. 1998.

38. Keleil A. User's Attitudes toward Fisheries Management on Lake Ziway, Ethiopia (Unpublished thesis work). 2002.

39. Kolding J. The fish resources of Lake Turkana and their environment. Unpublished Thesis for the Cand. Scient. Degree in Fisheries Biology. University of Bergen, Department of Fisheries Biology, Bergen, Norway. 1989.

40. Lemlem S. Biodiversity Potentials and Threats to the Southern, Rift Valley Lakes of Ethiopia. Proceedings of Seminar on the resources and status of Ethiopia's Wetlands, 2003:18-24.

41. Lévêque C, Oberdorff D, Paugy M, Stiassny T, Tedesco P. Global diversity of fish (Pisces) in fresh water. Hydrobiologia. 2008:545-567.

42. Lake Fisheries Development Working Paper (LFDP). Fisheries Baseline Survey, Lake Ziway Lake Fisheries Development Working Paper no 7.Addis Ababa, Ministry of Agriculture. 1993.

43. Matouš, P, Todo Y. "Roles of extension and ethno-religious networks in acceptance of resource-conserving agriculture among Ethiopian farmers". International Journal of Agricultural Sustain.2013;11(4):301-316. doi.org/10.1080/14735903.2012.7517 01

44. Mekonnen T, Muhammed S. Riverine fishery survey on Shinfa and Ghendwuha Rivers, in Metema Woreda, North Gondar Zone. Unpublished field Report. Fisheries resource research and training sub-center. Gorgora. 2002.

45. Merino G, Barange M, Blanchard J, Harle J, Holmes R, Allen I, et all. Can marine fisheries and aquaculture meet fish demand from a growing human population in a changing climate? Global Environmental Change. 2012;22(4):795-806.

46. Ministry of Agriculture and Rural Development (MoARD), Fisheries Development and Marketing Plan, Unpublished Document. Addis Ababa. Ethiopia. 2004.

47. Ministry of Water Resources (MOWR). Tekeze River basin integrated master plan project. Sectoral Report Fisheries. 1998.

48. Ministry of Finance and Economic Development (MoFED). Growth and Transformation Plan, 2010/11-2014/15, Volume I: Main Text. Ministry of Finance and Economic Development. FDRE. Addis Ababa.2010. 
49. Molle F. Planning and Managing Water Resources at the River Basin Level: Emergence and Evolution of Concepts. Comprehensive Assessment of Water Management in Agriculture. Research Report 16. 2006.

50. The Monthly Publication from the Ethiopian Embassy in London Ethiopian News. 2012.

51. Omer M. Diversity Relative Abundance and Biology of Fish in Upper Head of Blue Nile River, Blue Nile Basin, Ethiopia. MSc. Thesis Bahir Dar University. 2010.

52. Preston T. Feed resources for ruminants. In Tropical animal feeding, A manual for research workers of the Food and Agriculture Organization of the United Nations Rome. 1995. ISBN,92-5-103758-2.

53. Roberts TR. Geographical distribution of African freshwater fishes. Zool J Linn Soc. 1975;57:249- 319. DOI: 10.1111/j.1096-3642.1975. tb01893.x

54. Sandy D, Per Erik B. Stop illegal fishing and trade. 2008.

55. Sileshi A. Managing water for livestock and fisheries development. 2013.

56. Tarekegn S. Challenges of Sustainable Livelihood: The Case of Fishing Communities around Lake Chamo. 2006.
57.Teferi Y,AdmassuY, Mengistu S. Length-weight relationship, Body condition and sex ratio of tilapia (Oreochromis niloticus) in Lake Chamo, Ethiopia. SINET: Ethiop. J. Sci.2002;25:19-26.

58. Tesfaye G. Diversity, relative abundance and biology of fishes in Angereb and Sanja Rivers,Tekeze basin, Ethiopia. MSc. Thesis Addis Ababa. 2007.

59. Michele Thieme, Michele L Thieme, Robin Abell, Neil Burgess, Bernhard Lehner, Eric Dinerstein, et al. In Fresh water Eco region of Africa and Madagascar,2007:180-181.

60. Tsopito C. Crop residues as a feed source for ruminants. UNISWA Journal of Agri. 2003;12:29-34.

61. Vannuccini S. "Overview of Fish Production, Utilization, Consumption, and Trade." 2004.

62. Verschuren D, Thomas C, Hedy J, David N, Peter R, Erik T, et al. History and timing of human impact on Lake Victoria, East Africa. Proc R Soc Lond B Biol Sci. 2002;269:289-294. DOI: 10.1098/rspb.2001.1850

63. World Fish Center (WFC). Fish and Food Security in Africa. World Fish Center, Penang, Malaysia.2005.

64. Wood A. Dixon A .Sustainable wetland management in Illubabor zone:Research report summaries. The university of Huddersfield, Huddersfield. 2002. 